\title{
MULTILOCUS SEQUENCE ANALYSIS (MLSA) OF BRADYRHIZOBIUM STRAINS: REVEALING HIGH DIVERSITY OF TROPICAL DIAZOTROPHIC SYMBIOTIC BACTERIA
}

\author{
Jakeline Renata Marçon Delamuta ${ }^{1,2,3}$, Renan Augusto Ribeiro ${ }^{1,2,5}$, Pâmela Menna ${ }^{1,3}$, Eliane Villamil Bangel ${ }^{4}$, Mariangela \\ Hungria ${ }^{1,2,3, *}$
}

${ }^{1}$ Empresa Brasileira de Pesquisa Agropecuária - Soja, Londrina, PR, Brasil; ${ }^{2}$ Universidade Estadual de Londrina, Departamento Microbiologia, Londrina, PR, Brasil; ${ }^{3}$ Conselho Nacional de Desenvolvimento Científico e Tecnológico, Brasília, DF, Brasil; ${ }^{4}$ Fundação Estadual de Pesquisa Agropecuária, Porto Alegre, RS, Brasil; ${ }^{5}$ Fundação Araucária, Curitiba, PR, Brasil.

Submitted: April 18, 2011; Returned to authors for corrections: October 18, 2011; Approved: January 16, 2012.

\begin{abstract}
Symbiotic association of several genera of bacteria collectively called as rhizobia and plants belonging to the family Leguminosae (=Fabaceae) results in the process of biological nitrogen fixation, playing a key role in global $\mathrm{N}$ cycling, and also bringing relevant contributions to the agriculture. Bradyrhizobium is considered as the ancestral of all nitrogen-fixing rhizobial species, probably originated in the tropics. The genus encompasses a variety of diverse bacteria, but the diversity captured in the analysis of the 16S rRNA is often low. In this study, we analyzed twelve Bradyrhizobium strains selected from previous studies performed by our group for showing high genetic diversity in relation to the described species. In addition to the $16 \mathrm{~S}$ rRNA, five housekeeping genes (recA, $a t p D, g \ln I I, \operatorname{gyr} B$ and $r p o B$ ) were analyzed in the MLSA (multilocus sequence analysis) approach. Analysis of each gene and of the concatenated housekeeping genes captured a considerably higher level of genetic diversity, with indication of putative new species. The results highlight the high genetic variability associated with Bradyrhizobium microsymbionts of a variety of legumes. In addition, the MLSA approach has proved to represent a rapid and reliable method to be employed in phylogenetic and taxonomic studies, speeding the identification of the still poorly known diversity of nitrogen-fixing rhizobia in the tropics.
\end{abstract}

Key words: Biological nitrogen fixation; Bradyrhizobium; multilocus sequence analysis; phylogeny; taxonomy

\section{INTRODUCTION}

Species of the large family Leguminosae (Fabaceae in the USA) occupy a broad-range of terrestrial biomes, with several of them being capable of establishing symbioses with bacteria collectively called rhizobia, starting the process of fixing atmospheric nitrogen $\left(\mathrm{N}_{2}\right)$. Diazotrophic bacteria were first isolated from root nodules and characterized in 1888 by Martinus Willem Beijerinck (2) as Bacillus radicicola, but then reclassified into the genus Rhizobium, with the taxonomy based

*Corresponding Author. Mailing address: Embrapa Soja, Cx. Postal 231, 86001-970, Londrina, Paraná, Brazil.; Tel.: (+55)4333716206 Fax: (+55)4333716100.; E-mail: hungria@.cnpso.embrapa.br / hungria@pq.cnpq.br 
on nodulation with certain host plants, establishing the "crossinoculation group" concept (11). Taxonomical classification remained unaltered until the early 1980s, when numerical taxonomy considering morphological, physiological and genetic patterns led to the positioning of some strains into a new genus, Bradyrhizobium, with a unique defined species, $B$. japonicum (18). Bradyrhizobium includes slow growers that produce alkaline reaction in culture medium with mannitol as carbon source, while Rhizobium contains fast growing acid producers $(18,19)$.

A few years later, high diversity among Bradyrhizobium strains led to the description of a new species named Bradyrhizobium elkanii (23); however, the development of several molecular techniques helped to identify high genetic diversity among Bradyrhizobium strains isolated from a wide range of leguminous plants (e.g., 13, 28, 29, 46). Nowadays, there are nine defined Bradyrhizobium species (7), but certainly many more should be described in the next years.

Sequencing of the $16 \mathrm{~S}$ rRNA has become the method of choice for tracing bacterial phylogenies $(12,50,52)$, but in several genera including Bradyrhizobium variability in the $16 \mathrm{~S}$ rRNA is often low and may not reflect the diversity detected by other morpho-physiological and genetic properties (e.g., 13, 28, $42,46,51)$. To detect higher diversity, other ribosomal genes or regions have been chosen, as the $23 \mathrm{~S}$ rRNA and the $16 \mathrm{~S}-23 \mathrm{~S}$ rRNA intergenic transcribed spacer (ITS), since they evolve at a faster rate than the $16 \mathrm{~S}$ rRNA, thus adding valuable information to the analysis (e.g., 29, 41, 42, 46, 51). However, proximity of ribosomal genes might not properly indicate the correct phylogeny in the case of horizontal gene transfer (43).

The multilocus sequence analysis (MLSA) method has been increasingly used in phylogeny and taxonomy studies. The method consists of the analysis of several conserved housekeeping genes dispersed in at least $100 \mathrm{~kb}$ of the genome $(4,6,15,25)$. Successful definitions of phylogenetic groups of rhizobia have also been achieved with the use of the MLSA $(29,31,36)$.

Tropical rhizobia represent a key component for the sustainability of tropical soils, and the few results obtained so far clearly indicate that diversity is largely underestimated within the Bradyrhizobium genus $(13,28,29)$. Therefore in this study the MLSA approach was applied to achieve a better phylogenetic resolution of twelve strains showing high genetic diversity of the $16 \mathrm{~S}$ rRNA gene in relation to the described Bradyrhizobium species. The objective is to delineate strategies which may help to more promptly define diversity of tropical Bradyrhizobium.

\section{MATERIALS AND METHODS}

\section{Strains}

Twelve Bradyrhizobium strains were used in this study and are listed in Table 1. The strains were chosen from previous studies from our group $(3,13,28,29,37)$, based on the high level of genetic diversity observed in comparison to the described species of Bradyrhizobium. The strains have been isolated from members of two subfamilies and five tribes of the family Leguminosae, and originated from four countries located in different continents: Australia, Brazil, Malaysia and Zimbabwe (Table 1). The strains were purified on yeast extract-mannitol agar (YMA) medium (45) containing Congo red $(0.00125 \%)$ and stocks were prepared on YMA and kept at $-80^{\circ} \mathrm{C}$ (under $30 \%$ of glycerol) for long-term storage and at $4^{\circ} \mathrm{C}$ as source cultures. The strains are deposited at the "Culture Collection of Diazotrophic and PGPR Bacteria" of Embrapa Soja (http://www.bmrc.lncc.br) and at the Brazilian official culture collection "SEMIA" of rhizobial strains (IBP World Catalogue of Rhizobium Collections n ${ }^{\circ} 443$ in the WFCC World Data Center on Microorganisms). 
Table 1. Information about the Bradyrhizobium strains from the Embrapa Soybean culture collection used in this study

\begin{tabular}{|c|c|c|c|c|c|c|c|}
\hline $\begin{array}{l}\text { SEMIA } \\
\text { number }\end{array}$ & Other designations $^{\mathrm{a}}$ & $\begin{array}{l}\text { Origin of the } \\
\text { strain }\end{array}$ & $\begin{array}{c}\text { Country of } \\
\text { origin }\end{array}$ & Host species $^{\mathrm{b}}$ & Subfamily $^{b}$ & Tribe $^{b}$ & $\begin{array}{c}\text { Previous } \\
\text { studies }^{\mathrm{c}}\end{array}$ \\
\hline 656 & SEMIA original, CNPSo 988 & FEPAGRO & Brazil & $\begin{array}{l}\text { Neonotonia wightii (Wight } \\
\text { \& Arn.) Lackey }\end{array}$ & Papilionoideae & Phaseoleae & $a, b, d$ \\
\hline 662 & CB 188, CNPSo 990 & CSIRO & Australia & $\begin{array}{l}\text { Vigna unguiculata }(\mathrm{L} .) \\
\text { Walp }\end{array}$ & Papilionoideae & Phaseoleae & $a, b, d$ \\
\hline 696 & CB 627, CNPSo 993 & CSIRO & Australia & $\begin{array}{l}\text { Desmodium uncinatum } \\
\text { (Jacq.) DC }\end{array}$ & Papilionoideae & Demodieae & $\mathrm{a}, \mathrm{b}, \mathrm{d}, \mathrm{e}$ \\
\hline 6002 & $\begin{array}{l}\text { CB 756, TAL 309, RCR } 3824 \text {, } \\
\text { CNPSo } 1092\end{array}$ & CSIRO & Zimbabwe & $\begin{array}{l}\text { Vigna unguiculata }(\mathrm{L} .) \\
\text { Walp }\end{array}$ & Papilionoideae & Phaseoleae & $\mathrm{a}, \mathrm{b}, \mathrm{d}$ \\
\hline 6028 & $\begin{array}{l}\text { TAL 569, SPRL } 472 \text {, MAR } 472 \text {, } \\
\text { CNPSo } 1094\end{array}$ & NIFTAL & Zimbabwe & $\begin{array}{l}\text { Desmodium uncinatum } \\
\text { (Jacq.)DC }\end{array}$ & Papilionoideae & Demodieae & $a, b, d$ \\
\hline 6053 & $\begin{array}{l}\text { TAL 827, UMKL 28, CNPSo } \\
1095\end{array}$ & NIFTAL & Malaysia & Clitoria ternatea $\mathrm{L}$. & Papilionoideae & Phaseoleae & $\mathrm{a}, \mathrm{b}, \mathrm{d}, \mathrm{e}$ \\
\hline 6144 & $\begin{array}{l}\text { SMS 400, USDA } 3187 \text {, MAR } \\
11 \text {, CNPSo } 1109\end{array}$ & IAC & Zimbabwe & Arachis hypogaea L. & Papilionoideae & Aeschynomeneae & $a, b, d$ \\
\hline 6145 & BR 2001, CNPSo 1110 & $\begin{array}{l}\text { Embrapa } \\
\text { Agrobiologia }\end{array}$ & Brazil & Crotalaria juncea $\mathrm{L}$. & Papilionoideae & Crotalarieae & $a, b, d$ \\
\hline 6148 & SMS 303, CNPSo 1112 & IAC & Brazil & $\begin{array}{l}\text { Neonotonia wightii (Wight } \\
\text { \& Arn.) Lackey }\end{array}$ & Papilionoideae & Phaseoleae & $a, b, d$ \\
\hline 6154 & BR 446, CNPSo 1117 & $\begin{array}{l}\text { Embrapa } \\
\text { Agrobiologia }\end{array}$ & Brazil & Stylosanthes spp. & Papilionoideae & Aeschynomeneae & $\mathrm{a}, \mathrm{c}, \mathrm{e}$ \\
\hline 6160 & BR 5610, CNPSo 1123 & $\begin{array}{l}\text { Embrapa } \\
\text { Agrobiologia }\end{array}$ & Brazil & Albizia lebbeck (L.) Benth. & Mimosoideae & Ingeae & $a, b, d$ \\
\hline 6395 & BR 4301, CNPSo 1161 & $\begin{array}{l}\text { Embrapa } \\
\text { Agrobiologia }\end{array}$ & Brazil & $\begin{array}{l}\text { Calliandra houstoniana } \\
\text { (Mill.) Standl. }\end{array}$ & Mimosoideae & Ingeae & $\mathrm{c}$ \\
\hline
\end{tabular}

${ }^{a}$ Culture collections: BR (Brazil, Embrapa Agrobiologia, Seropédica, Brazil); CB (Commonwealth Scientific and Industrial a Research Organization - CSIRO, Canberra, Australia); CNPSo (Centro Nacional de Pesquisa de Soja, Brazil); MAR (Marondera, Grasslands Rhizobium Collection, Soil Productivity Research Laboratory, Marondera, Zimbabwe; also called SPRL); SEMIA (Seção de Microbiologia Agrícola, FEPAGRO, Porto Alegre, Brazil); SMS (Seção de Microbiologia do Solo, IAC, Campinas, Brazil); TAL (NifTAL, Nitrogen Fixation by Tropical Agricultural Legumes Project, University of Hawaii, Paia, USA); USDA (United States Department of Agriculture, Beltsville,

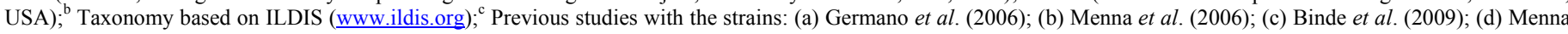
et al. (2009); (e) Roma Neto et al. (2010).

\section{DNA extraction and sequencing analysis of the $16 \mathrm{~S}$ rRNA}

The DNA samples were extracted from bacterial batch cultures grown in YM broth until late exponential phase $\left(10^{9}\right.$ cells $\mathrm{mL}^{-1}$ ) as described before (20). The DNAs were submitted to the amplification with primers for the $16 \mathrm{~S}$ rRNA, recA, $a t p D, g \ln I I, g y r B$ and $r p o B$ genes, as listed in Table 2. The PCR products were purified with the PureLink ${ }^{\mathrm{TM}}$ PCR Purification Kit (Invitrogen), and the reactions for the sequencing analysis contained purified PCR products of each bacterium culture ( $80 \mathrm{ng}$ per reaction), $3 \mu \mathrm{L}$ of dye (DYEnamic ET terminator reagent premix for the MEGA BACE) and 3 pmol of each primer (Table 2). The conditions of PCR amplification were as described by Menna et al. (28). The sequencing was performed on a MEGA BACE 1000 (Amersham Biosciences) capillary sequencer according to the manufacturer's instructions.

Table 2. Primers and DNA amplification conditions used in this study

\begin{tabular}{|c|c|c|c|c|}
\hline Primer & Sequence $(5-3)^{a}$ & Target gene (position) $\dagger$ & PCR cycling & Reference \\
\hline TSrecAf & CAACTGCMYTGCGTATCGTCGAAGG & $\operatorname{rec} A(8-32)$ & $2 \min 95^{\circ} \mathrm{C}, 35 \mathrm{X}\left(45 \mathrm{~s} 95^{\circ} \mathrm{C}, 30 \mathrm{~s} 58^{\circ} \mathrm{C}\right.$ & Stepkowski et al. (2005) \\
\hline TSrecAr & CGGATCTGGTTGATGAAGATCACCATG & $\operatorname{rec} A(620-594)$ & $1,5 \min 72^{\circ} \mathrm{C}$ and $7 \min 72^{\circ} \mathrm{C}$ & \\
\hline TSatpDf & TCTGGTCCGYGGCCAGGAAG & atpD (189-208) & $2 \min 95^{\circ} \mathrm{C}, 35 \mathrm{X}\left(45 \mathrm{~s} 95^{\circ} \mathrm{C}, 30 \mathrm{~s} 58^{\circ} \mathrm{C}\right.$ & Stepkowski et al. (2005) \\
\hline TSatpDr & CGACACTTCCGARCCSGCCTG & atpD (804-784) & $1,5 \min 72^{\circ} \mathrm{C}$ and $7 \min 72^{\circ} \mathrm{C}$ & \\
\hline TSglnIIf & AAGCTCGAGTACATCTGGCTCGACGG & $g \ln I I(13-38$ & $2 \min 95^{\circ} \mathrm{C}, 35 \mathrm{X}\left(45 \mathrm{~s} 95^{\circ} \mathrm{C}, 30 \mathrm{~s} 58^{\circ} \mathrm{C}\right.$ & Stepkowski \\
\hline TSglnIIr & SGAGCCGTTCCAGTCGGTGTCG & $g \ln I I(681-660)$ & $1,5 \min 72^{\circ} \mathrm{C}$ and $7 \min 72^{\circ} \mathrm{C}$ & \\
\hline gyrB343F & TTCGACCAGAAYTCCTAYAAGG & $\operatorname{gyrB}(343-364)$ & $5 \min 95^{\circ} \mathrm{C}, 5 \mathrm{X}\left(2 \min 94^{\circ} \mathrm{C}, 2 \min \right.$ & Martens et al. (2008) \\
\hline gyrB1043R & AGCTTGTCCTTSGTCTGCG & $\operatorname{gyr} B(1061-1043)$ & $\begin{array}{l}\left.58^{\circ} \mathrm{C}, 1 \min 72^{\circ} \mathrm{C}\right) 28 \times\left(30 \mathrm{~s} 94^{\circ} \mathrm{C}, 1\right. \\
\min 58^{\circ} \mathrm{C}, 1 \min 72^{\circ} \mathrm{C} \text { and } 5 \min 72^{\circ} \mathrm{C} \text {. }\end{array}$ & \\
\hline rpoB83F & CCTSATCGAGGTTCACAGAAGGC & $\operatorname{rpoB}(8$ & $5 \min 95^{\circ} \mathrm{C}, 3 \mathrm{X}\left(2 \min 94^{\circ} \mathrm{C}, 2 \min \right.$ & Martens et al. (2008) \\
\hline rpoB1061R & AGCGTGTTGCGGATATAGGCG & $\operatorname{rpoB}(1081-1061)$ & $\begin{array}{l}\left.58^{\circ} \mathrm{C}, 1 \min 72^{\circ} \mathrm{C}\right) 30 \times\left(30 \mathrm{~s} 94^{\circ} \mathrm{C}, 1\right. \\
\min 58^{\circ} \mathrm{C}, 1 \min 72^{\circ} \mathrm{C} \text { and } 5 \min 72^{\circ} \mathrm{C} \text {. }\end{array}$ & \\
\hline fD1 & AGAGTTTGATCCTGGCTCAG & 16S rRNA (9-29) & $2 \min 95^{\circ} \mathrm{C}, 30 \mathrm{X}\left(15 \mathrm{~s} 94^{\circ} \mathrm{C}, 45 \mathrm{~s} 93^{\circ} \mathrm{C}\right.$ & Weisburg et al. (1991) \\
\hline $\mathrm{rD} 1$ & CTTAAGGAGGTGATCCAGCC & 16S rRNA (1474-1494) & $45 \mathrm{~s} 55^{\circ} \mathrm{C}, 2 \min 72^{\circ} \mathrm{C}$ and $5 \min 72^{\circ} \mathrm{C}$ & \\
\hline
\end{tabular}

${ }^{\text {a }}$ Mixtures of bases used at certain positions are given as: $\mathrm{K}, \mathrm{T}$ or G; S, G or C; Y, C or T; R, A or G; M, A or C

$\dagger$ Position of the primer in the corresponding sequence of Bradyrhizobium japonicum USDA 110 


\section{Cluster analyses}

The 16S rRNA, recA, atpD, glnII, gyrB and $r p o B$ sequences generated were analyzed with the programs Phred (8, 9), Phrap (http://www.phrap.org) and Consed (16). The consensus sequences obtained and confirmed in the $5^{\prime}$ and $3^{\prime}$ directions were submitted to the GenBank database and received the accession numbers listed in Table 3. Some genes have been previously sequenced by our group, but were resequenced in this study; as the identities were confirmed in $100 \%$ of the nucleotide bases, the original accession numbers were maintained (Table 3). Sequences for other reference/type strains were retrieved from the GenBank database and are also listed in Table 3. Caulobacter crescentus strain CB 15 (genome, AE005673), was used as an outgroup.
The MLSA analysis was performed considering only the complete aligned sequences (size among parenthesis) obtained for the Bradyrhizobium strains and for the type/reference strains retrieved from GenBank: 16S rDNA (1,347 bp), recA (293 bp), atpD (395 bp), glnII (442 bp), gyrB (434 bp) and rров (395 bp).

All sequences obtained in this study or retrieved from GenBank were analyzed individually and concatenated using the MEGA (Molecular Evolutionary Genetics Analysis) software version 4.0 with the default parameters, K2P distance model (21), and the Neighbor-Joining algorithm (38). Statistical support for tree nodes was evaluated by bootstrap (10) analyses with 1000 samplings (17).

Table 3. GenBank/EMBL/DDBJ accession numbers for the sequences of the Bradyrhizobium strains used in this study and of the reference/type strains

\begin{tabular}{|c|c|c|c|c|c|c|}
\hline Strain & 6S rRNA & $\operatorname{rec} A$ & atpD & $g \ln I I$ & gyrB & rpoB \\
\hline \multicolumn{7}{|c|}{ Bradyrhizobium strains } \\
\hline SEMIA 656 & AY904732a & FJ391146 & FJ390946 ${ }^{\mathrm{c}}$ & FJ391026 ${ }^{\mathrm{c}}$ & HQ634882 & HQ634901 ${ }^{\mathrm{e}}$ \\
\hline SEMIA 662 & AY904734 & HQ634894 & HQ634871 ${ }^{\mathrm{e}}$ & HQ634877 ${ }^{\mathrm{e}}$ & HQ634883 ${ }^{\mathrm{e}}$ & HQ634902 \\
\hline SEMIA 696 & AY904736 $6^{\mathrm{a}}$ & HQ634895 & & GQ160506 $6^{\mathrm{d}}$ & HQ634884 & HQ634903 \\
\hline SEMIA 6002 & AY904743 ${ }^{\mathrm{a}}$ & HQ634896 & HQ634872 & HQ634878 & HQ634885 & HQ634904 \\
\hline SEMIA 6028 & AY904744 & FJ391159c & FJ390959 & FJ391039 & HQ634886 ${ }^{\mathrm{e}}$ & HQ634905 \\
\hline SEMIA 6053 & AY904745 & FJ391160 ${ }^{c}$ & FJ390960 ${ }^{c}$ & $\mathrm{FJ} 391040^{\mathrm{c}}$ & HQ634887 $7^{\mathrm{e}}$ & HQ634906 ${ }^{\mathrm{e}}$ \\
\hline SEMIA 6144 & AY904750 & HQ634897 ${ }^{\mathrm{e}}$ & HQ634873 ${ }^{\mathrm{e}}$ & HQ634879e & HQ634888 & HQ634907 \\
\hline SEMIA 6145 & AY904751 ${ }^{\mathrm{a}}$ & HQ634898 & HQ634874 & HQ634880 & HQ634889 & HQ634908 \\
\hline SEMIA 6148 & AY904753 ${ }^{\mathrm{a}}$ & FJ391168 & FJ390968 & FJ391048 & HQ634890 & HQ634909e \\
\hline SEMIA 6154 & $\mathrm{FJ} 025100^{\mathrm{b}}$ & HQ634899e & HQ634875 ${ }^{\mathrm{e}}$ & GQ160500 ${ }^{\mathrm{d}}$ & HQ634891 ${ }^{\mathrm{e}}$ & HQ634910 \\
\hline SEMIA 6160 & AY904762a & FJ391171 c & FJ390971 ${ }^{c}$ & FJ391051 & HQ634892 & HQ634911 ${ }^{\mathrm{e}}$ \\
\hline SEMIA 6395 & FJ025101 ${ }^{\mathrm{b}}$ & HQ634900 & HQ634876 ${ }^{\mathrm{e}}$ & HQ634881 & HQ634893 & HQ634912 \\
\hline \multicolumn{7}{|c|}{ Reference/type strains } \\
\hline B. betae LMG $21987^{\mathrm{T}}$ & AY372184 & $\mathrm{AB} 353734^{\mathrm{f}}$ & FM253129f & $A B 353733^{f}$ & FM253217 f & FM $253260^{\mathrm{f}}$ \\
\hline B. jicamae $\mathrm{PAC} 68^{\mathrm{T}}$ & AY $624134^{f}$ & HM047133 ${ }^{\mathrm{f}}$ & FJ428211 ${ }^{\mathrm{f}}$ & FJ428204 ${ }^{\mathrm{f}}$ & HQ873309 ${ }^{\mathrm{f}}$ & HQ587647 ${ }^{f}$ \\
\hline B. pachyrhizi PAC $48^{\mathrm{T}}$ & AY624135 & HM047130 f & FJ428208 ${ }^{\mathrm{f}}$ & FJ428201 ${ }^{\mathrm{f}}$ & HQ873310 & HQ587648 ${ }^{\mathrm{f}}$ \\
\hline B. canariense LMG $22265^{\mathrm{T}}$ & AJ558025 & FM253177 $7^{\mathrm{f}}$ & AY386739 & AY386765 & FM $253220^{f}$ & FM $253263^{f}$ \\
\hline B. yuanmingense LMG $21827^{\mathrm{T}}$ & AF $193818^{f}$ & AM $168343^{f}$ & AY386760 & AY386780f & FM $253226^{f}$ & FM $253269^{\mathrm{f}}$ \\
\hline B. liaoningense LMG $18230^{\mathrm{T}}$ & AF208513 ${ }^{\mathrm{f}}$ & AY591564 & AY386752 $2^{\mathrm{f}}$ & AY $386775^{\mathrm{f}}$ & FM $253223^{\mathrm{f}}$ & FM253266 ${ }^{\mathrm{f}}$ \\
\hline B. elkanii USDA $76^{\mathrm{T}}$ & $\mathrm{U} 35000^{\mathrm{f}}$ & AY591568 & AY386758 $8^{\mathrm{f}}$ & AY599117 & AM418800 & AM295348 \\
\hline B. japonicum USDA $6^{\mathrm{T}}$ & $X 66024^{\mathrm{f}}$ & AM182158 & AM168320 & AF $169582^{f}$ & AM418801 ${ }^{\mathrm{f}}$ & AM295349 \\
\hline B. iriomotense EK05 & $\mathrm{AB} 300992^{\mathrm{f}}$ & $A B 300996^{\mathrm{f}}$ & AB300994 & $\mathrm{AB} 300995^{\mathrm{f}}$ & $\mathrm{AB} 300997^{\mathrm{f}}$ & HQ587646 ${ }^{\mathrm{f}}$ \\
\hline Rhizobium tropici CIAT $899^{\mathrm{T}}$ & EU488752 ${ }^{\mathrm{f}}$ & EU488815 & AM418789 & EU488791 ${ }^{\mathrm{f}}$ & AM418836 & AM $295354^{\mathrm{f}}$ \\
\hline Rhizobium etli CFN $42^{\mathrm{T}}$ & EU488751 ${ }^{\mathrm{f}}$ & EU488824 & ${ }^{+} \mathrm{NC} 007761^{\mathrm{f}}$ & EU488776 f & ${ }^{+} \mathrm{NC} 007761^{\mathrm{f}}$ & ${ }^{+} \mathrm{NC} 007761^{\mathrm{f}}$ \\
\hline Rhizobium rhizogenes ATCC $11325^{\mathrm{T}}$ & AY945955 & AM $182126^{\mathrm{f}}$ & $\mathrm{AM} \overline{4} 18786^{\mathrm{f}}$ & FJ816281 ${ }^{\mathrm{f}}$ & $\mathrm{AM} \overline{4} 18833^{\mathrm{f}}$ & AM $295353^{\mathrm{f}}$ \\
\hline Mesorhizobium loti LMG $6125^{\mathrm{T}}$ & $X 67229^{\mathrm{f}}$ & AM182156 & AM946552 $2^{f}$ & AF $169581^{\mathrm{f}}$ & EU273810 & ${ }^{+} \mathrm{A} 000012.4^{\mathrm{f}}$ \\
\hline Mesorhizobium huakuii USDA $4779^{\mathrm{T}}$ & $\mathrm{D} 13431^{\mathrm{f}}$ & AJ $294370^{\mathrm{f}}$ & AJ294394 f & AF $169588^{\mathrm{f}}$ & $\mathrm{AM} 076344^{\mathrm{f}}$ & FJ393283 ${ }^{\mathrm{f}}$ \\
\hline
\end{tabular}




\section{RESULTS}

\section{Diversity in the $16 \mathrm{~S}$ rRNA}

The phylogenetic tree built with the 16S rRNA sequences split the Bradyrhizobium strains in two large groups, with final bootstrap supports for each group of 70 and $94 \%$, respectively (Fig. 1). The first group (G-I) comprised eight SEMIA strains, all grouped with $B$. elkanii and also with $B$. pachyrhizi and $B$. jicamae. The second group (G-II) included SEMIAs 6395, 656, 6002 and 6144 showing closer relation with B. iriomotense, in addition to reference/type strains of $B$. betae, $B$. canariense, $B$. yuanmingense, B. liaoningense and B. japonicum. Fig. 1 also highlights that the clustering analysis based on the 16S rRNA gene did not define clear positions for the SEMIA strains.

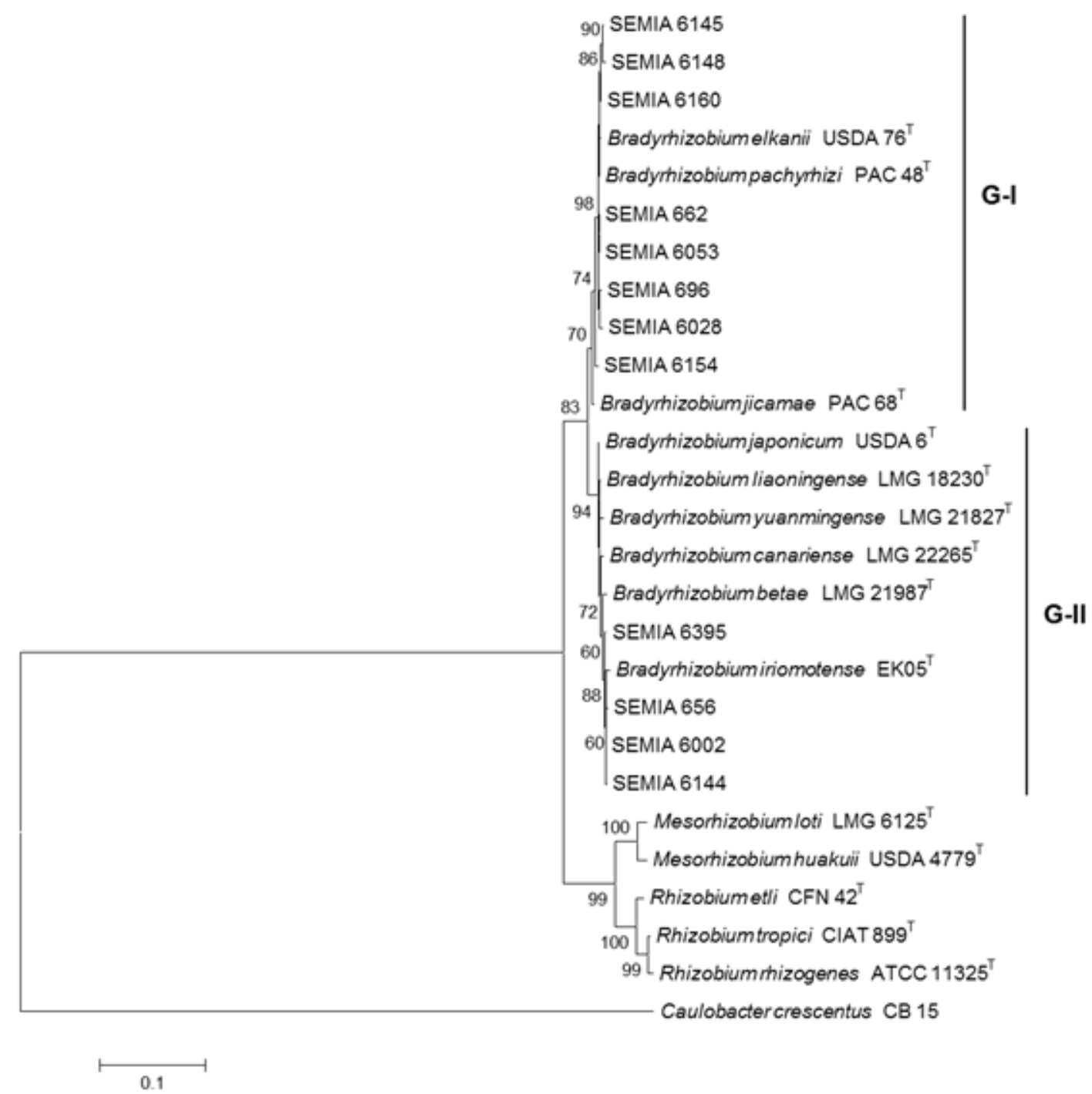

Figure 1. Phylogenetic relationships of Bradyrhizobium strains from this study and of reference/type rhizobial strains based on the 16S rRNA. Phylogeny was inferred using the Neighbor-Joining method. The percentage of replicate trees in which the associated taxa clustered together in the bootstrap test (1,000 replicates) are shown next to the branches. The tree is drawn to scale, with branch lengths in the same units as those of the evolutionary distances used to infer the phylogenetic tree. All positions containing gaps and missing data were eliminated from the dataset (Complete deletion option). Phylogenetic analyses were conducted in MEGA4. 


\section{Diversity in the atpD, glnII, gyrB, $\operatorname{rec} A$ and $r p o B$ genes}

The additional housekeeping genes selected to refine the phylogeny analysis in this study are highly conserved among bacteria of the order Rhizobiales, are dispersed in the genome of B. japonicum strain USDA 110 and encode important proteins. For each housekeeping gene, phylogenetic trees were constructed and resulted in distinct groups (Fig. 2).

When compared to the $16 \mathrm{~S}$ rRNA, higher variability was detected in the analysis of the $\operatorname{rec} A$ gene, and strains also fit into two groups (Fig. 2A). All four strains previously positioned in G-II of the $16 \mathrm{~S}$ rRNA were closer to $B$. iriomotense, but with the appearance of at least one subgroup including SEMIA 6002 and SEMIA 6144 strains. This first group of strains had a high bootstrap support, of $99 \%$. Subgroups were even more evident with the strains previously positioned in G-I of the 16S rRNA, with the delineation of four subgroups based on the recA gene: one including strains SEMIAs 6160, 662 and B. pachyrhizi, the second with SEMIA 696 and B. elkanii and two new subgroups including exclusively SEMIA strains, one with SEMIAs 6148 and 6154 and the other with SEMIAs 6028, 6053 and 6145. These subgroups had bootstrap supports ranging from 81 to $99 \%$ (Fig. 2A).

Greater variability was also observed with atpD gene (Fig. $2 \mathrm{~B})$, when compared to the $16 \mathrm{~S}$ rRNA. The tree built with the $a t p D$ gene resulted in the definition of three main groups (G-I, G-II and G-III), with a final bootstrap support of $81 \%$. Although the DNA of strain SEMIA 696 amplified with the $a t p D$ primers, sequencing of the fragment failed, therefore the strain was not included in the analysis. In G-I, strains were split in two subgroups, the first clustering four strains with higher resemblance with $B$. elkanii, and the second with three strains grouping with $B$. pachyrhizi (Fig. 2B). The other four SEMIA strains from this study were positioned in G-III of the atpD tree, with SEMIA 6395 showing higher similarity with $B$. betae, while the other strains were grouped with $B$. liaoningense (Fig. 2B).

The tree built with the $g \ln I I$ gene also resulted in two groups. In G-I four SEMIA strains were clustered with $B$. pachyrhizi, SEMIA 696 was clustered with B. elkanii, followed by the inclusion of SEMIA 662 and B. jicamae (Fig. 2C). In GII of the $g \ln I I$, it is worth mentioning the clustering of strains SEMIAs 6002 and 6144 with a bootstrap support of 97\% (Fig. 2C), also confirmed with high support in the previous trees of recA (Fig. 2A) and $a t p D$ (Fig. 2B), but not well defined in the 16S rRNA (Fig. 1).

In the trees built with the $g y r B$ and $r p o B$ genes the strains were also split in two groups, with the formation of a third group in the gyrB tree, which clustered only the type strains of $B$. betae and $B$. canariense. In general, a better definition of the strains positioned in G-I of the $16 \mathrm{~S}$ rRNA (Fig. 1) was not achieved with the analysis of the $g y r B$ (Fig. 2D) and $r p o B$ (Fig. $2 \mathrm{E})$ genes. The other four SEMIAs analyzed were positioned in G-II in both trees. In G-II of gyrB, the SEMIA 6395 clustered with B. iriomotense, while SEMIAs 656, 6002 and 6144 were closer to $B$. yuanmingense. In the $r p o B$ tree, these four SEMIAs were clustered in two well defined subgroups (6566395 and 6002-6144).

It is also interesting that, excepting for the atpD gene, $B$. pachyrhizi, B. jicamae and B. elkanii were positioned in the same group in the analysis of the $16 \mathrm{~S}$ rRNA, recA, glnII, gyrB and $r p o B$ (Fig. 1 and Figs. 2A to 2E). On the other hand, definition of the other Bradyrhizobium species considered in this study was not completely clear when considering those genes (Fig. 1 and Figs. 2A to 2E).

From the analysis of the $16 \mathrm{~S}$ rRNA (Fig. 1) and of five housekeeping genes (Fig. 2), the division of Bradyrhizobium in two main groups was clear, with the appearance of a third group not completely well defined only in the trees built with the $a t p D$ and $g y r B$ genes. Each SEMIA strain used in our study was always positioned in the same great group in all six trees. 
A)

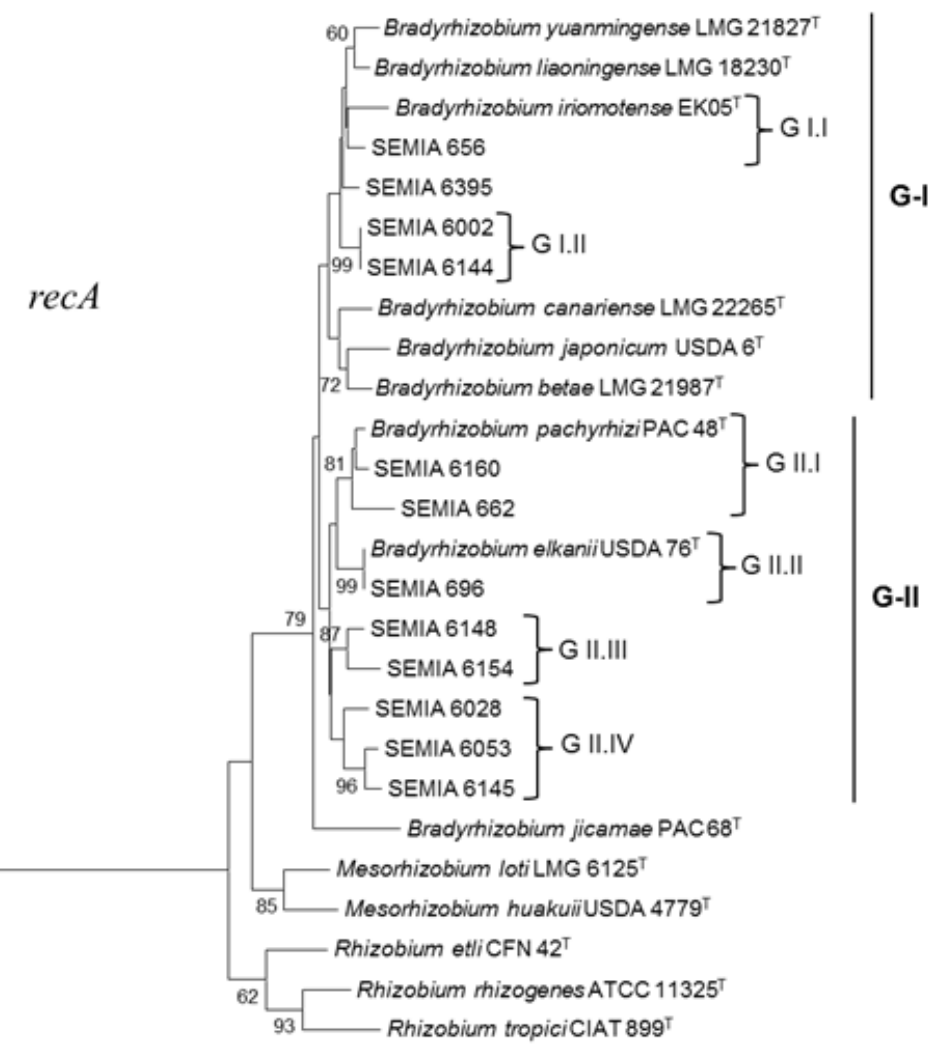

B)

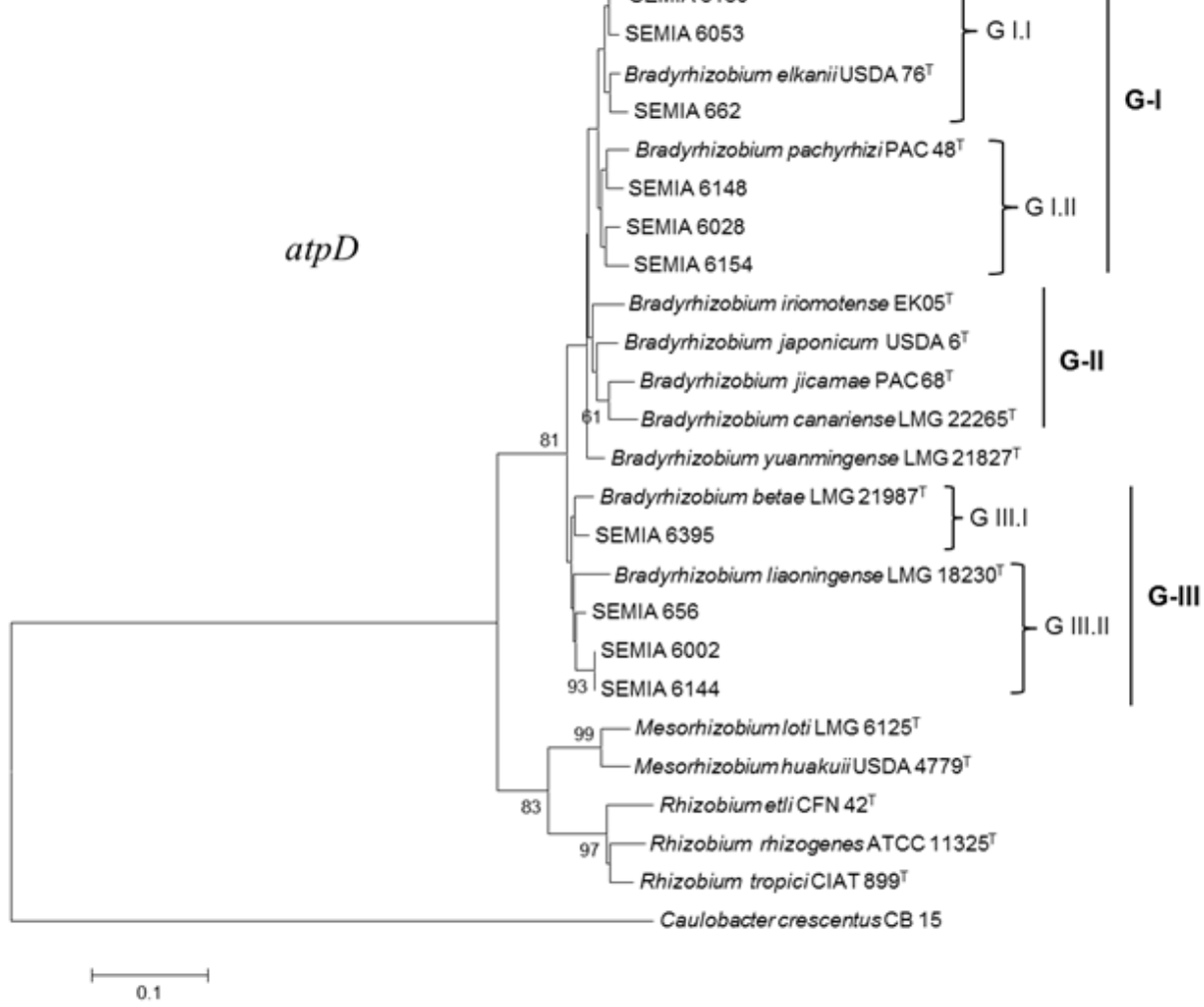


C)
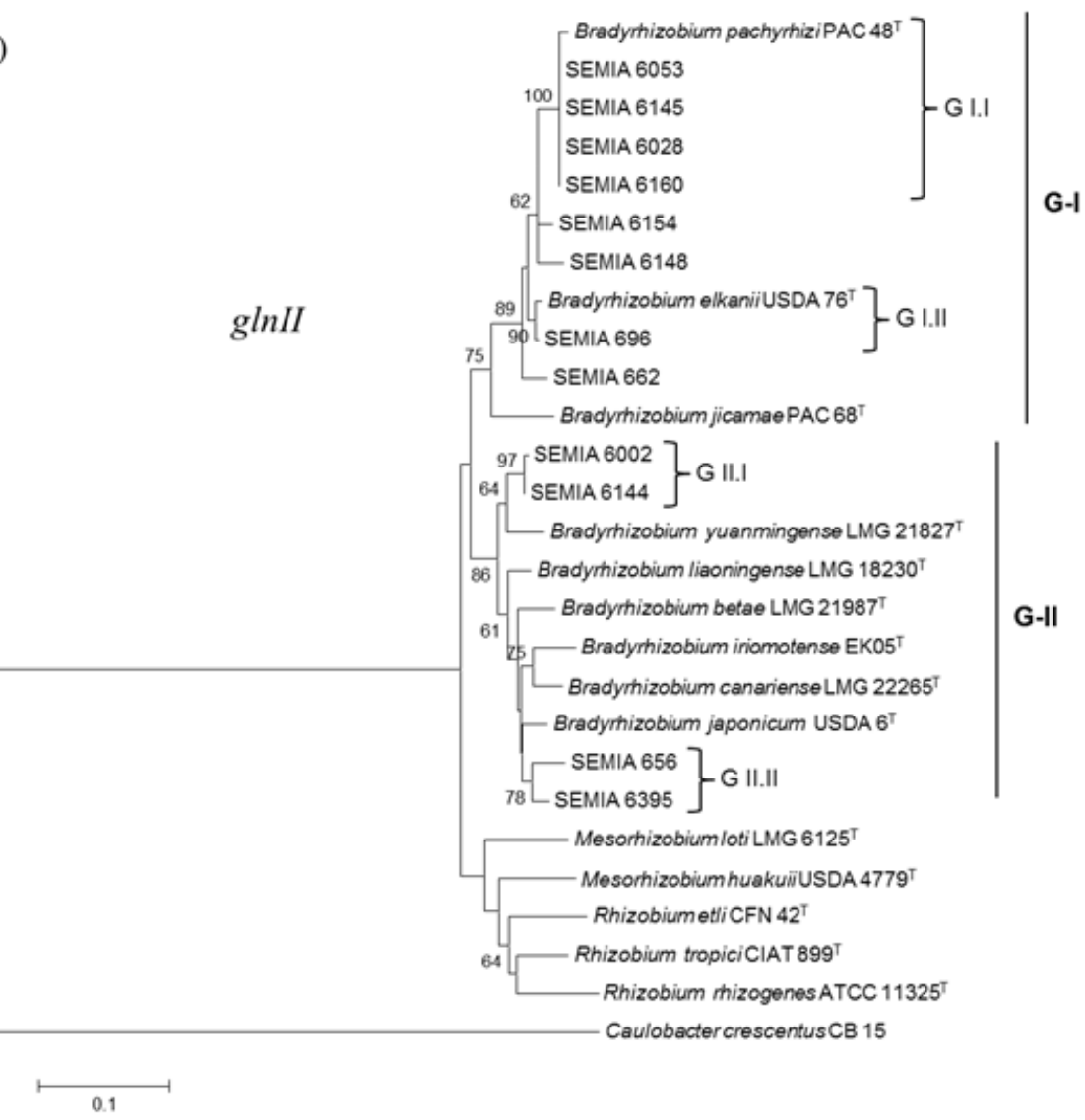

D)

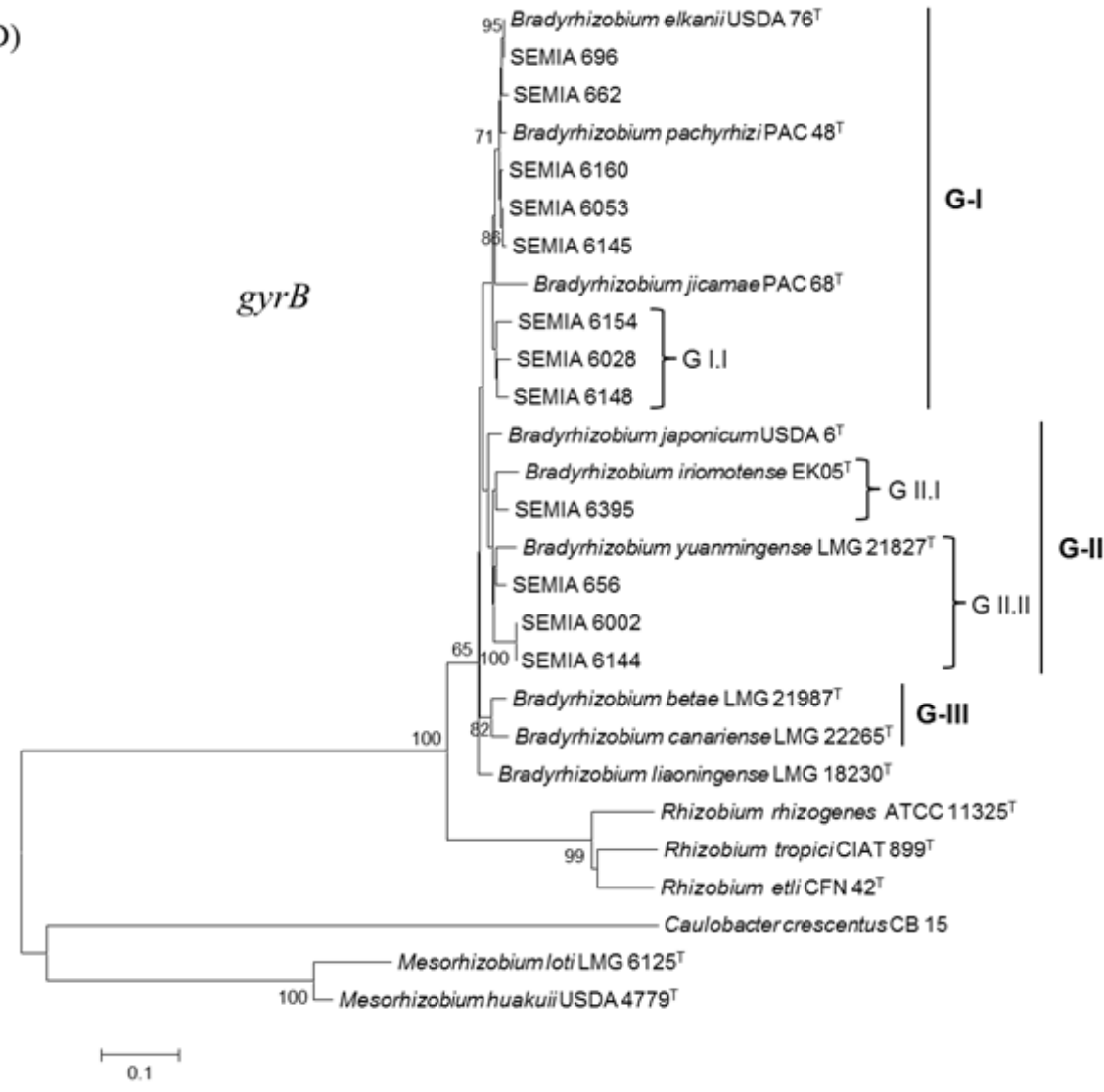




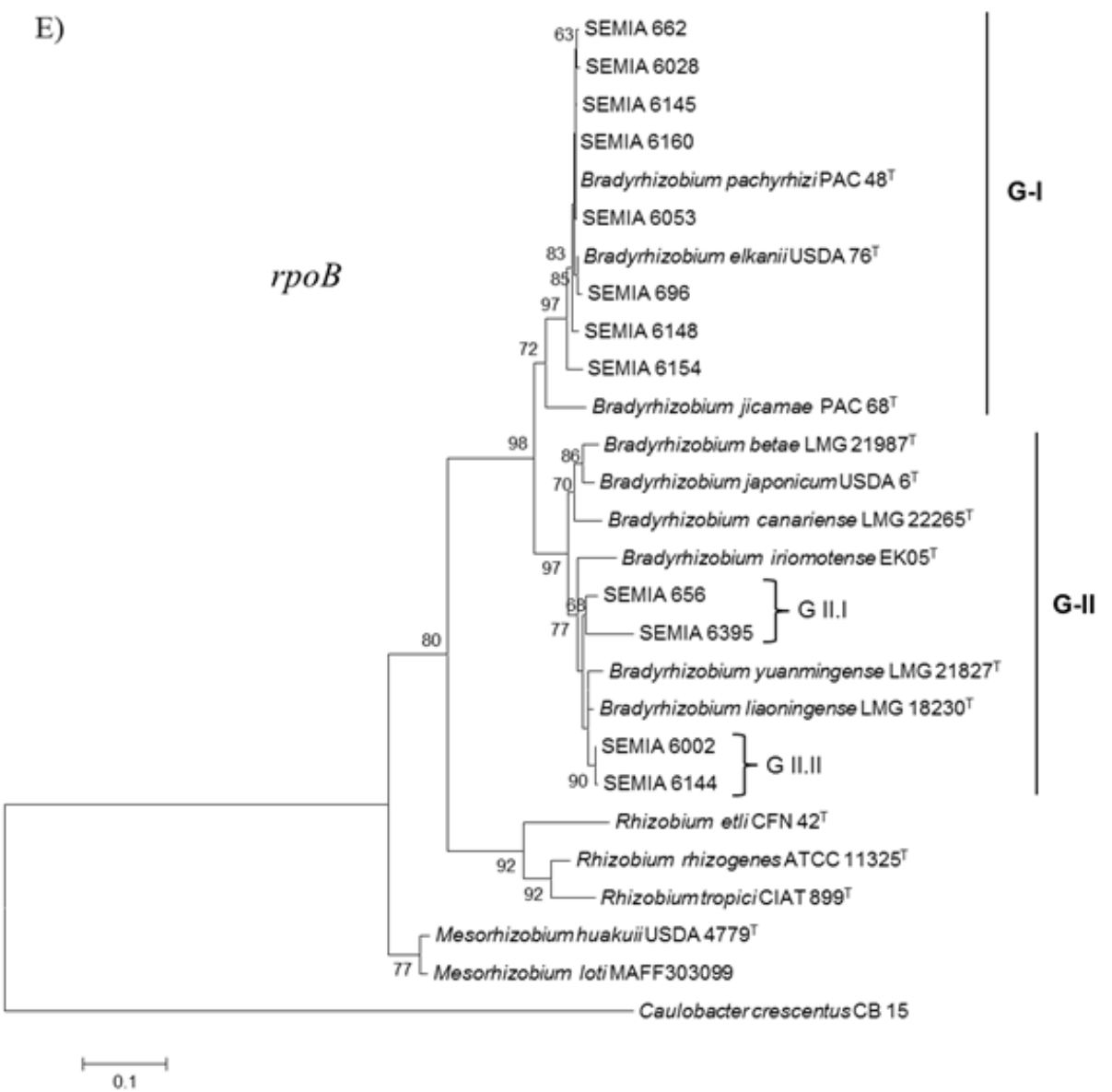

Figure 2. Phylogenetic relationships of Bradyrhizobium strains from this study and of reference/type rhizobial strains based on the (A) $r e c A$, (B) $a t p D,(C) g \ln I I$, (D) gyrB and (E) $r p o B$ genes. Method and parameters of analysis were as described for Figure 1.

\section{Concatenated analysis of $\operatorname{rec} A$, atpD, glnII, gyrB and $\operatorname{rpoB}$}

All five sequences of the housekeeping genes were concatenated to gain a better understanding of the strains; SEMIA 696 was not included. A concatenated sequence with $1,959 \mathrm{bp}$ was obtained and 2,028 sites were analysed, resulting in 1,496 conserved, 463 variable and 304 parsimonyinformative sites (Table 4).

The tree built with the concatenated genes resulted in two great groups, with a bootstrap support of $100 \%$ (Fig. 3). G-I assembled SEMIAs 656, 6395, 6002 and 6144 together with type/reference strains of $B$. yuanmingense, $B$. liaoningense, $B$. iriomotense, B. japonicum, B. betae and B. canariense. Within G-I, subclusters that were not well defined in the $16 \mathrm{~S}$ rRNA (Fig. 1) tree were now shown (Fig. 3), including the pairs of strains SEMIAs 656-6395 and SEMIAs 6002-6144, with bootstrap supports of 95 and $100 \%$, respectively. The results highlight that these strains deserve further studies, as they may represent new species. The concatenated tree has also detected higher diversity of the strains occupying G-II, with the SEMIAs 6160, 6028, 6053 and 6145 showing similarity with the type strain of B. pachyrhizi. The pair of strains 6148-6154 could also represent a new species. Finally, it is important to mention that in all trees Bradyrhizobium was clearly apart from the other rhizobial genera.

Another important observation is that clustering of strains by means of both $16 \mathrm{~S}$ rRNA and housekeeping genes showed no relation with the host plant. Strains clustered in G-I of the MLSA were isolated from subfamilies Papilionoideae 
(SEMIAs 656, 6002 and 6144) and Mimosoideae (SEMIA 6395), and G-II also included strains from both subfamilies. Other examples refer to isolates from Vigna, clustered in both
G-I (SEMIA 6002) and G-II (SEMIA 662), while isolates from tribe Ingeae were clustered in both G-I (SEMIA 6395) and G-II (SEMIA 6160) of the MLSA (Fig. 3).

Table 4. Sequence information obtained in this study. Twelve strains were analysed, together with nine type and reference strains, as described in Methods.

\begin{tabular}{|c|c|c|c|c|c|c|}
\hline \multirow[t]{2}{*}{ Locus } & \multirow{2}{*}{$\begin{array}{l}\text { Strains analysed } \\
(n)\end{array}$} & \multicolumn{4}{|c|}{ Nucleotides (\%) } & \multirow[t]{2}{*}{ Frequency T/C/A/G (\%) } \\
\hline & & Conserved & Variable & $\begin{array}{l}\text { Parsimony- } \\
\text { informative }\end{array}$ & Total* & \\
\hline 16S rRNA & 21 & $1,266(91,5)$ & $86(6,2)$ & $52(3,7)$ & $1,347 / 1,383$ & 20.4/24.0/24.7/30.9 \\
\hline atpD & 20 & $318(77,6)$ & $77(18,8)$ & $57(13,9)$ & $395 / 410$ & $15.7 / 33.3 / 19.6 / 31.3$ \\
\hline$g \ln I I$ & 21 & $334(72,8)$ & $108(23,5)$ & $77(16,8)$ & $442 / 459$ & $16.2 / 32.7 / 19.9 / 31.2$ \\
\hline gyrB & 21 & $338(74,8)$ & $96(21,2)$ & $56(12,4)$ & $434 / 452$ & 21.7/29.9/16.5/32.0 \\
\hline rec $A$ & 21 & $217(72,6)$ & $76(25,4)$ & $52(17,4)$ & $293 / 299$ & $15.8 / 32.3 / 17.3 / 34.7$ \\
\hline rров & 21 & $287(70,8)$ & $108(26,7)$ & $63(15,5)$ & $395 / 405$ & $17.4 / 32.8 / 18.7 / 31.1$ \\
\hline Concatenated genes & 20 & $1,496(73,7)$ & $463(22,8)$ & $304(15)$ & $1,959 / 2,028$ & $17.5 / 32.2 / 18.4 / 31.9$ \\
\hline
\end{tabular}

* Mean number of nucleotides amplified/number of sites analysed, including gaps.

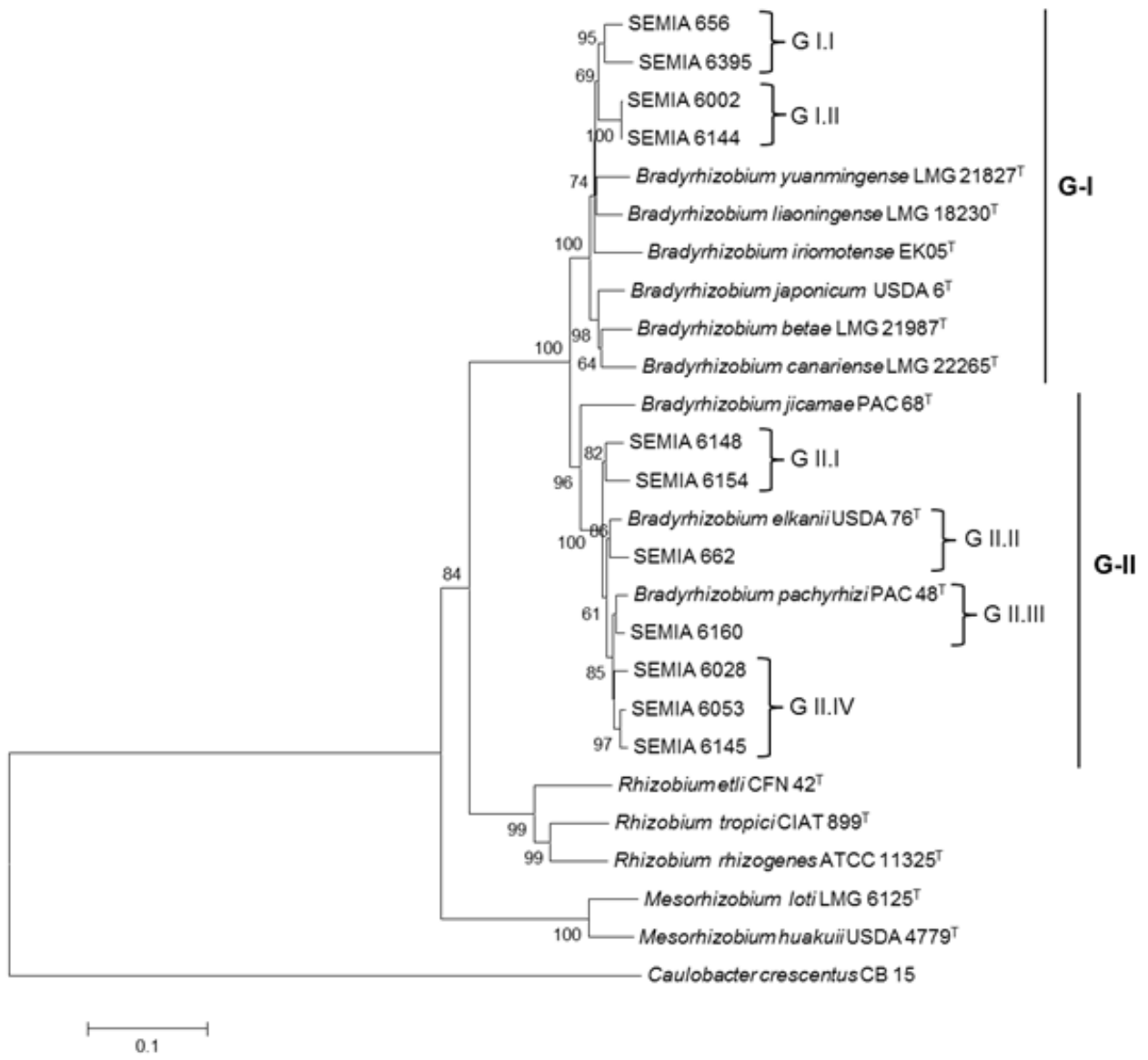

Figure 3. Evolutionary tree inferred using the Neighbor-Joining method for 22 strains based on concatenated genes (recA, atpD, glnII, gyrB, rроB). The percentage of replicate trees in which the associated strains clustered together in the bootstrap test (1,000 replicates) are shown next to the branches. The tree is drawn to scale, with branch lengths in the same units as those of the evolutionary distances used to infer the phylogenetic tree. Codon positions included were $1 \mathrm{st}+2 \mathrm{nd}+3 \mathrm{rd}+$ noncoding. All positions containing gaps and missing data were eliminated from the dataset (Complete deletion option). Phylogenetic analyses were conducted in MEGA4. 


\section{DISCUSSION}

Bradyrhizobium is an intriguing genus of bacteria encompassing a number of interesting features. First, the genus has been considered as the ancestor of all rhizobia $(24,32,35$, 49), and it has been isolated from a variety of legumes distributed worldwide. However, the great majority of the reports on diversity and genetics of diazotrophic symbiotic bacteria has been performed with fast-growing rhizobia, thus studies with Bradyrhizobium may reveal new insights into the evolution of rhizobia. The second important feature is that Bradyrhizobium has probably originated in the tropical region $(24,32)$, and indeed bradyrhizobia seem to represent the majority of the isolates from leguminous trees in Brazilian tropical forests (30). As it has been pointed out since the pioneer studies of ribosomal genes, apparently there are many more varieties of rhizobia in tropical and subtropical than in temperate regions $(33,46)$; therefore, studies on the genetic diversity of Bradyrhizobium may expose a high level of genetic diversity. Finally, the third important feature relies on the reports of high rates of nitrogen fixation related to bacteria belonging to the genus Bradyrhizobium (14), and excellent examples comprise the symbioses with cowpea (Vigna spp.) and soybean (Glycine max). Indeed, the SEMIA strains used in our study are highly effective in fixing nitrogen with their host plants.

Previous studies from our group employing analyses of the 16S rRNA, 23S rRNA, ITS and housekeeping genes have indicated an unexpected genetic diversity of Bradyrhizobium $(13,28,29)$. In our study the use of five housekeeping genes in the MLSA approach highlighted a far higher diversity in comparison to the single analysis with the $16 \mathrm{~S}$ rRNA, clearly indicating putative new species.

DNA-DNA hybridization is still required to define new species (12), but arguments against its obligatory use have been raised, including: high cost and intensive work $(5,44)$, existence of more accurate approaches (22), doubts about its adequacy (1). MLSA has then been proposed as a more accessible tool for assessing phylogeny and taxonomy of prokaryotes $(4,6,15,25)$. Also in this context, the use of at least four housekeeping genes for the phylogenetic analysis and taxonomic classification of bradyrhizobia has been proposed (29, 34, 39, 40, 48), and was confirmed as a successful approach in our study.

It is also interesting that host specificity was not related to genetic clustering, confirming previous reports from our group $(3,13,28,29,37)$, and indicating that other genes must be searched aiming at getting a better understanding of the evolution of the symbioses, probably nodulation and nitrogen fixation genes.

Biological nitrogen fixation plays a key role in the environment and agriculture sustainability. The results from our study highlight the high genetic variability associated with Bradyrhizobium microsymbionts of a variety of legumes. Our results confirm that the MLSA approach can represent an important, effective, fast and low-cost strategy to reveal the still poorly known diversity of Bradyrhizobium and certainly other nitrogen-fixing rhizobial species $(26,29,36,40,47)$. In our study MLSA clearly contributed to a better phylogeny definition, as well as to the identification of new subgroups indicative of new species.

\section{ACKNOWLEDGEMENTS}

The work was partially supported by CNPq (Conselho Nacional de Desenvolvimento Científico e Tecnológico, Brazil), CNPq-PNPD (558455/2008-5), CNPq/MCT/MAPA (577933/2008), CNPq-Universal (470162/2009) and CNPqRepensa (562008/2010-1).

\section{REFERENCES}

1. Achtman, M.; Wagner, M. (2008). Microbial diversity and the genetic nature of microbial species. Nat. Rev. Microbiol. 6, 431-440.

2. Beijerinck, M.W. (1888). Cultur des Bacillus radicicola aus den 
Knöllchen. Bot. Ztg. 46, 740-750.

3. Binde, D.R.; Menna, P.; Bangel, E.V.; Barcellos, F.G.; Hungria, M. (2009). rep-PCR fingerprinting and taxonomy based on the sequencing of the 16S rRNA gene of 54 elite commercial rhizobial strains. Appl. Microbiol. Biotechnol. 83, 897-908.

4. Brett, P.J.; Deshazer, D.; Woods, D.E. (1998). Burkholderia thailandensis sp. nov., a Burkholderia pseudomallei-like species. Int. J. Syst. Evol. Microbiol. 48, 317-320.

5. Coenye, T.; Gevers, D.; Van de Peer, Y.; Vandamme, P.; Swings, J. (2005). Towards a prokaryotic genomic taxonomy. FEMS Microbiol. Rev. 29, 147-167.

6. Cooper, J.E.; Feil, E.J. (2004). Multilocus sequence typing - what is resolved? Trends Microbiol. 12, 373-377.

7. DSMZ - Deutsche Sammlung von Mikroorganismen und Zellkulturen GmbH (German Collection of Microorganisms and Cell Cultures). 2010. Available at: http://www.dsmz.de/index.htm. Accessed 11 Nov 2010.

8. Ewing, B.; Green, P. (1998). Base-calling of automated sequencer traces using phred. II. Error probabilities. Genome Res. 8, 186-194.

9. Ewing, B.; Hillier, L.; Wendl, M.C.; Green, P. (1998). Base-calling of automated sequencer traces using phred. I. Accuracy assessment. Genome Res. 8, 175-185.

10. Felsenstein, J. (1985). Confidence limits on phylogenies: an approach using the bootstrap. Evolution. 39, 783-791.

11. Fred, E.B.; Baldwin, I.L.; McCoy, E. (1932). Root Nodule Bacteria of Leguminous Plant. Madison, University of Wisconsin Press.

12. Garrity, G.M.; Holt, J.G. (2001). The roadmap to themanual. In: Boone, D.R., Castenholz, R.W., Garrity, G.M. (eds). 2ed. Bergey's Manual of Systematic Bacteriology. Springer, New York, USA, p.119-166.

13. Germano, M.G.; Menna, P.; Mostasso, F.L.; Hungria, M. (2006). RFLP analysis of the rRNA operon of a Brazilian collection of bradyrhizobial strains from 33 legume species. Int. J. Syst. Evol. Microbiol. 56, 217229.

14. Giller, K.E. (2001). Nitrogen fixation in tropical cropping systems. $2^{\text {nd }}$ ed. CABI Publishing, Wallingford, UK.

15. Godoy, D.; Randle, G.; Simpson, A.J.; Aanensen, D.M.; Pitt, T.L.; Kinoshita, R.; Spratt, B.G. (2003). Multilocus sequence typing and evolutionary relationships among the causative agents of melioidosis and glanders, Burkholderia pseudomallei and Burkholderia mallei. J. Clin. Microbiol. 41, 2068-2079.

16. Gordon, D.; Abajian, C.; Green, P. (1998). Consed: a graphical tool for sequence finishing. Genome Res. 8, 195-202.

17. Hedges, S.B. (1992). The number of replications needed for accurate estimation of the bootstrap p-value in phylogenetic studies Mol. Biol. Evol. 9, 366-369.

18. Jordan, D.C. (1982). Transfer of Rhizobium japonicum Buchanan 1980 to Bradyrhizobium gen. nov., a genus of slow-growing, root nodule bacteria from leguminous plants. Int. J. Syst. Bacteriol. 32, 136-139.

19. Jordan, D.C. (1984). Family III. Rhizobiaceae Conn 1938. In: Krieg, N.R., Holt, J.G. (eds). Bergey's Manual of Systematic Bacteriology. Williams \& Wilkens Co.., Baltimore, USA, p.234-235.

20. Kaschuk, G.; Hungria, M.; Andrade, D.S.; Campo, R.J. (2006). Genetic diversity of rhizobia associated with common bean (Phaseolus vulgaris L.) grown under no-tillage and conventional systems in Southern Brazil. Appl. Soil Ecol. 32, 210-220.

21. Kimura, M. (1980). A simple method for estimating evolutionary rates of base substitutions through comparative studies of nucleotide sequences. J. Mol. Evol. 16, 111-120.

22. Konstantinidis, K.T.; Tiedje, J.M. (2004). Trends between gene content and genome size in prokaryotic species with larger genomes. Proc. Natl. Acad. Sci. USA. 101, 3160-3165.

23. Kuykendall, L.D.; Saxena, B.; Devine, T.E.; Udell, S.E. (1992). Genetic diversity in Bradyrhizobium japonicum Jordan 1982 and a proposal for Bradyrhizobium elkanii sp. nov. Can. J. Microbiol. 38, 501-505.

24. Lloret, L.; Martínez-Romero, E. (2005). Evolución y filogenia de Rhizobium. Rev. Latinoam. Microbiol. 47, 43-60.

25. Maiden, M.C.J.; Bygraves, J.A.; Feil, E.; Morelli, G.; Russell, J.E.; Urwin, R.; Zhang, Q.; Zhou, J.; Zurth, K.; other authors (1998). Multilocus sequence typing: a portable approach to the identification of clones within populations of pathogenic microorganisms. Proc. Natl. Acad. Sci. USA. 95, 3140-3145.

26. Martens, M.; Delaere, M.; Coopman, R.; De Vos, P.; Gillis, M.; Willems, A. (2007). Multilocus sequence analysis of Ensifer and related taxa. Int. J. Syst. Evol. Microbiol. 57, 489-503.

27. Martens, M.; Dawyndt, P.; Coopman, R.; Gillis, M.; De Vos, P.; Willems, A. (2008). Advantages of multilocus sequence analysis for taxonomic studies: a case study using 10 housekeeping genes in the genus Ensifer (including former Sinorhizobium). Int. J. Syst. Evol. Microbiol. 58, 200-214.

28. Menna, P.; Hungria, M.; Barcellos, F.G.; Bangel, E.V.; Hess, P.N.; Martínez-Romero, E. (2006). Molecular phylogeny based on the $16 \mathrm{~S}$ rRNA gene of elite rhizobial strains used in Brazilian commercial inoculants. Syst. Appl. Microbiol. 29, 315-332.

29. Menna, P.; Barcellos, F.G.; Hungria, M. (2009). Phylogeny and taxonomy of a diverse collection of Bradyrhizobium strains based on Multilocus Sequence Analysis of the 16S rRNA gene, ITS region and glnII, recA, atpD and dnaK genes. Int. J. Syst. Evol. Microbiol. 59, 29342950.

30. Moreira, F.M.S. (1991). Caracterização de estirpes de rizóbio isoladas de espécies florestais pertencentes a diversos grupos de divergência de Leguminosae introduzidas ou nativas da Amazônia e Mata Atlântica. Rio de Janeiro, Brasil. (Ph.D. Thesis. Universidade Federal Rural do Rio de Janeiro. UFRRJ). 
31. Moulin, L.; Béna, G.; Boivin-Masson, C.; Stepkowski, T. (2004). Phylogenetic analysis of symbiotic nodulation genes support vertical and lateral gene co-transfer within the Bradyrhizobium genus. Mol. Phylogenet. Evol. 30, 720-732.

32. Norris, D.O. (1965). Acid production by Rhizobium: a unifying concept. Plant Soil. 22, 143-166.

33. Oyaizu, H.; Naruhashi, N.; Gamou, T. (1992). Molecular methods of analysing bacterial diversity: the case of rhizobia. Biodivers. Conserv. 1, 237-249.

34. Parker, M.A. (2004). rRNA and dnaK relationships of Bradyrhizobium sp. nodule bacteria from four Papilionoid legume trees in Costa Rica. Syst. Appl. Microbiol. 27, 334-342.

35. Provorov, N.A.; Vorob'ev, N.I. (2000). Evolutionary genetics of nodule bacteria: molecular and populational aspects. Russ. J. Genet. 36, $1323-$ 1335.

36. Ribeiro, R.A.; Barcellos, F.G.; Thompson, F.L.; Hungria, M. (2009). Multilocus sequence analysis of Brazilian Rhizobium microsymbionts of common bean (Phaseolus vulgaris L.) reveals unexpected taxonomic diversity. Res. Microbiol. 160, 297-306.

37. Roma Neto, I.V.; Ribeiro, R.A.; Hungria, M. (2010). Genetic diversity of elite rhizobial strains of subtropical and tropical legumes based on the 16S rRNA and glnII genes. World J. Microbiol. Biotechnol. 26, 12911302.

38. Saitou, N.; Nei, M. (1987). The neighbor-joining method: a new method for reconstructing phylogenetic trees. Mol. Biol. Evol. 4, 406-425.

39. Stepkowski, T.; Czaplínska, M.; Miedzinska, K.; Moulin, L. (2003). The variable part of the $d n a K$ gene as an alternative marker for phylogenetic studies of rhizobia and related alpha Proteobacteria. Syst. Appl. Microbiol. 26, 483-494.

40. Stepkowski, T.; Moulin, L.; Krzyzanska, A.; McInnes, A.; Law, I.J.; Howieson, J. (2005). European origin of Bradyrhizobium populations infecting lupins and serradella in soils of western Australia and South Africa. Appl. Environ. Microbiol. 71, 7041-7052.

41. Tesfaye, M.; Holl, F.B. (1998). Group-specific differentiation of Rhizobium from clover species by PCR amplification of 23S rDNA sequences. Can. J. Microbiol. 44, 1102-1105.

42. van Berkum, P.; Fuhrmann, J.J. (2000). Evolutionary relationships among the soybean bradyrhizobia reconstructed from 16S rRNA gene and internally transcribed spacer region sequence divergence. Int. J. Syst.
Evol. Microbiol. 50, 2165-2172.

43. van Berkum, P.; Terefework, Z.; Paulin, L.; Suomalainen, S.; Lindstrom, K.; Eardly, B.D. (2003). Discordant phylogenies within the rrn loci of rhizobia. J. Bacteriol. 185, 2988-2998.

44. Vandamme, P.; Pot, B.; Gillis, M.; De Vos, P.; Kersters, K.; Swings, J. (1996). Polyphasic taxonomy, a consensus approach to bacterial systematics. Microbiol. Rev. 60, 407-438.

45. Vincent, J.M. (1970). Manual for the practical study of root nodule bacteria. Blackwell Scientific, Oxford, UK (IBP Handbook No. 15).

46. Vinuesa, P.; Rademaker, J.L.W.; de Bruijn, F.J.; Werner, D. (1998). Genotypic characterization of Bradyrhizobium strains nodulating endemic woody legumes of the canary islands by PCR-restriction fragment length polymorphism analysis of genes encoding 16S rRNA (16S rDNA) and 16S-23S rDNA intergenic spacers, repetitive extragenic palindromic PCR genomic fingerprinting, and partial 16S rDNA sequencing. Appl. Environ. Microbiol. 64, 2096-2104.

47. Vinuesa, P.; León-Barrios, M.; Silva, C.; Willems, A.; Jarabo-Lorenzo, A.; Pérez-Galdona, R.; Werner, D.; Martínez-Romero, E. (2005a). Bradyrhizobium canariense sp. nov., an acid-tolerant endosymbiont that nodulates endemic genistoid legumes (Papilionoideae: Genisteae) from the Canary Islands, along with Bradyrhizobium japonicum bv. genistearum, Bradyrhizobium genospecies alpha and Bradyrhizobium genospecies beta. Int. J. Syst. Evol. Microbiol. 55, 569-575.

48. Vinuesa, P.; Silva, C.; Werner, D.; Martínez-Romero, E. (2005b). Population genetics and phylogenetic inference in bacterial molecular systematics: the roles of migration and recombination in Bradyrhizobium species cohesion and delineation. Mol. Phylogenet. Evol. 34, 29-54.

49. Wang, E.T.; Martínez-Romero, E. (2000). Phylogeny of root- and stemnodule bacteria associated with legumes. In: Triplett, E.W. (ed). Prokaryotic Nitrogen Fixation: a model system for analysis of a biological process. Horizon Scientific, Wymondham, UK, p.177-186.

50. Weisburg, W.G.; Barns, S.M.; Pelletier, D.A.; Lane, D.J. (1991). 16S ribossomal DNA amplification for phylogenetic study. J. Bacteriol. 173, 697-703.

51. Willems, A.; Doignon-Bourcier, F.; Goris, J.; Coopman, R.; de Lajudie, P.; De Vos, P.; Gillis, M. (2001). DNA-DNA hybridization study of Bradyrhizobium strains. Int. J. Syst. Evol. Microbiol. 51, 1315-1322.

52. Woese, C.R. (1987). Bacterial evolution. Microbiol. Rev. 51, 221-271. 